\title{
Scanning electron microscopy and freeze-etching of gonorrhoeal urethral exudate
}

\author{
HOMAYOON FARZADEGAN* AND IVAN L. ROTH \\ Department of Microbiology, University of Georgia, Athens, Georgia 30602, U.S.A.
}

The pathology of gonorrhoea and the mechanisms by which Neisseria gonorrhoeae establishes disease have not been thoroughly elucidated. It has been reported that the entrance of the $N$. gonorrhoeae cells into the epithelial tissue of the urethral tract in the male takes place through the intercellular spaces and reaches the subepithelial connective tissue 3 or 4 days after exposure to an infected female (Harkness, 1948). The urethral discharge in the male is the result of the migration of polymorphonuclear leucocytes, lymphocytes, and plasma cells to the site of infection beneath the columnar epithelium. The presence of gonococci in leucocytes in the urethral exudate is the most important diagnostic evidence of gonorrhoeal infection in the male (Ovčinnikov and Delektorskij, 1971; Spink, 1937). Thomas, Hill, and Tyeryar (1973) reported that cells from type 1 colonies of $N$. gonorrhoeae strain F62 (Kellogg, Peacock, Deacon, Brown, and Pirkle, 1963; Kellogg, Cohen, Norins, Schroeter, and Reising, 1968) survived phagocytosis by human leucocytes better than cells from type 4 colonies. The ultrastructure of phagocytes and gonococci in urethral exudate has been studied by observation of thin sections (Ovčinnikov and Delektorskij, 1971; Ward and Watt, 1972; Ward, Glynn, and Watt, 1972). Although these reports contain valuable information, thin sections provide only a two-dimensional image of dehydrated, embedded specimens. It was the purpose of this investigation to develop methods for the study of phagocytes and the relationship between $N$. gonorrhoeae and phagocytes in the urethral discharge of males suffering from gonorrhoea, at the threedimensional level by scanning electron microscopy and by the use of the freeze-etch technique and the observation of replicas in the transmission electron microscope.

\section{Material and methods}

\section{GONORRHOEAL URETHRAL EXUDATE}

Urethral exudate was obtained from male patients with characteristic symptoms of gonorrhoea who reported to the Clarke County Public Health Department, Athens,

Received for publication July 24, 1974

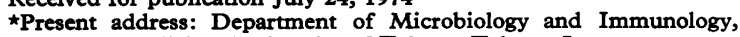
School of Medicine, University of Tehran, Tehran, Iran
Georgia, U.S.A., for treatment. Diagnosis of gonorrhoea was made by microscopical examination of a Gram-stained smear of the exudate and by culture on modified LesterMartin medium (Martin and Lester, 1971). The microorganisms on the plate were identified as Gram-negative diplococci which showed a positive oxidase reaction with $\mathrm{N}, \mathrm{N}^{\prime}$-dimethyl-P-phenylenediamine monohydrochloride (Eastman Kodak Co., Rochester, New York). When cultures were obtained on a transparent medium (GC base, Difco, Detroit, Mich.) supplemented with supplements I and II (Difco), approximately 85 per cent. of the colonies were Type 1, 12 per cent. were Type 2 , and the remaining 3 per cent. were Types 3 and 4 . These organisms were further identified as $N$. gonorrhoeae, in that they fermented glucose, but failed to ferment lactose, sucrose, maltose, fructose, or mannitol.

PREPARATION FOR SCANNING ELECTRON MICROSCOPY Specimens of urethral exudate were prepared for scanning electron microscopy by using the critical point drying technique of Anderson (1951). The specimens were fixed in 2 per cent. glutaraldehyde (Polysciences, Inc., Warrington, Pennsylvania) in $0.1 \mathrm{M}$ cacodylate buffer at pH $7 \cdot 0$ for 2 hrs at room temperature. Dehydration was achieved by passing the specimens through 70 per cent. ethyl alcohol (U.S. Industrial Chemical Company, New York) for $15 \mathrm{~min}$., 95 per cent. ethyl alcohol for $15 \mathrm{~min}$., and finally 100 per cent. ethyl alcohol for $30 \mathrm{~min}$., with two changes. Then the specimens were suspended in a 1:1 solution of ethanol and amyl acetate (J. T. Baker Chemical Company, Phillipsburg, New Jersey) for $30 \mathrm{~min}$. with two changes. The specimens were next placed in undiluted amyl acetate for $30 \mathrm{~min}$. with two changes. Then the specimens were placed on a scanning electron microscope stub and the excess amyl acetate was drained. The stubs were then placed on a specimen holder and inserted into the critical point bomb. The amyl acetate was replaced by liquid $\mathbf{C O}_{2}$. After all of the amyl acetate was exhausted from the bomb, it was sealed and heated to $40-42^{\circ} \mathrm{C}$. The pressure in the bomb was monitored and maintained in excess of $1200 \mathrm{lb}$./sq. in. When the temperature was stabilized at $40-42^{\circ} \mathrm{C}$., the gas was released slowly via the exhaust valve. The temperature was maintained above $40^{\circ} \mathrm{C}$. until all the gas was removed. The dried specimens were then metal coated with gold: palladium (60: 40) (Ladd Research Industries, Burlington, $\mathrm{Vt}$.) at two different angles on a rotary stage in a vacuum evaporator (Varian Model Number VE10). 'Specimens were observed at an angle of $45^{\circ}$ in the Cambridge Stereoscan Mark 2A scanning electron microscope at an accelerating voltage of $8 \mathrm{kV}$. Photographs were made with 
a Polaroid $4 \times 5$ Land Film Holder 500 using Polaroid P/N 55 film.

PREPARATION OF SPECIMENS FOR FREEZE-ETCHING Specimens of urethral exudate were fixed in 2 per cent. glutaraldehyde in $0.1 \mathrm{M}$ cacodylate buffer at $\mathrm{pH} 7.0$ for $2 \mathrm{hrs}$ at room temperature. A 30 per cent. (v/v) aqueous solution of glycerol was used as a cryoprotective agent. Then specimens were frozen in Freon 22 for 40 sec., and then kept in liquid nitrogen. A Balzer freeze-etching unit was used in this investigation. Etching times were 8 to $10 \mathrm{~min}$. Shadowing time was $8 \mathrm{sec}$. Carbon coating was continued for $10 \mathrm{sec}$. The replica was washed in 100 per cent. Clorox (5.2 per cent. sodium hypochlorite, Clorox Company, New York) overnight at $0^{\circ} \mathrm{C}$. and in 48 per cent. hydrofluoric acid (Mallinckrodt Chemical Works, St. Louis, Missouri) for $\mathbf{4} \mathrm{hrs}$ at room temperature. Grids (400 mesh) were used to support the replica. A Philips 200 transmission electron microscope was used to observe the replicas at $80-100 \mathrm{kV}$.

\section{Results}

Figs 1 and 2 show scanning electron micrographs of urethral exudate from a male with gonorrhoea. The exudate was prepared for observation by the critical point drying technique. Fig. $1 a$ shows at low magnification such a preparation. Most of the phagocytes (P) are stuck to each other and are seen as a clump of cells. Fig. $1 b$ shows at higher magnification the surface of the phagocytes. The surface appears to be extensively ruffled. Fig. 2 shows scanning electron micrographs of epithelial cells. The cell in Fig. $2 a$ appears to be flattened against the supporting surface of the stub. The large protrusion at the right of the epithelial cell appears to be somewhat different from the rest of the cell. The epithelial cell in Fig. $2 b$ does not show such a protrusion but does have a flattened appearance. The surface of both cells (Figs $2 a, \mathrm{~b}$ ) is extensively convoluted.

Fig. 3 shows a freeze-etched preparation of urethral exudate from a male patient. A phagocyte, which appears to be a polymorphonuclear phagocyte, is seen in this micrograph. This phagocyte does not contain identifiable cells of $N$. gonorrhoeae in the plane of fracture. Three lobes of the nucleus $(\mathrm{N})$ are visible. The nuclear membrane (nm) and nuclear pores are seen in this figure. Pseudopodia (ps) and the smooth outer surface (os) structure of this phagocyte are readily seen. The inner track of the nuclear membrane has a rough appearance as compared to the outer layer which is smooth. The cytoplasm is filled with granules (G) of different sizes.

Fig. 4 shows a phagocyte revealing the appearance of nuclear pores (unlabelled arrows) along with invaginations of the membrane toward the centre of the nucleus.

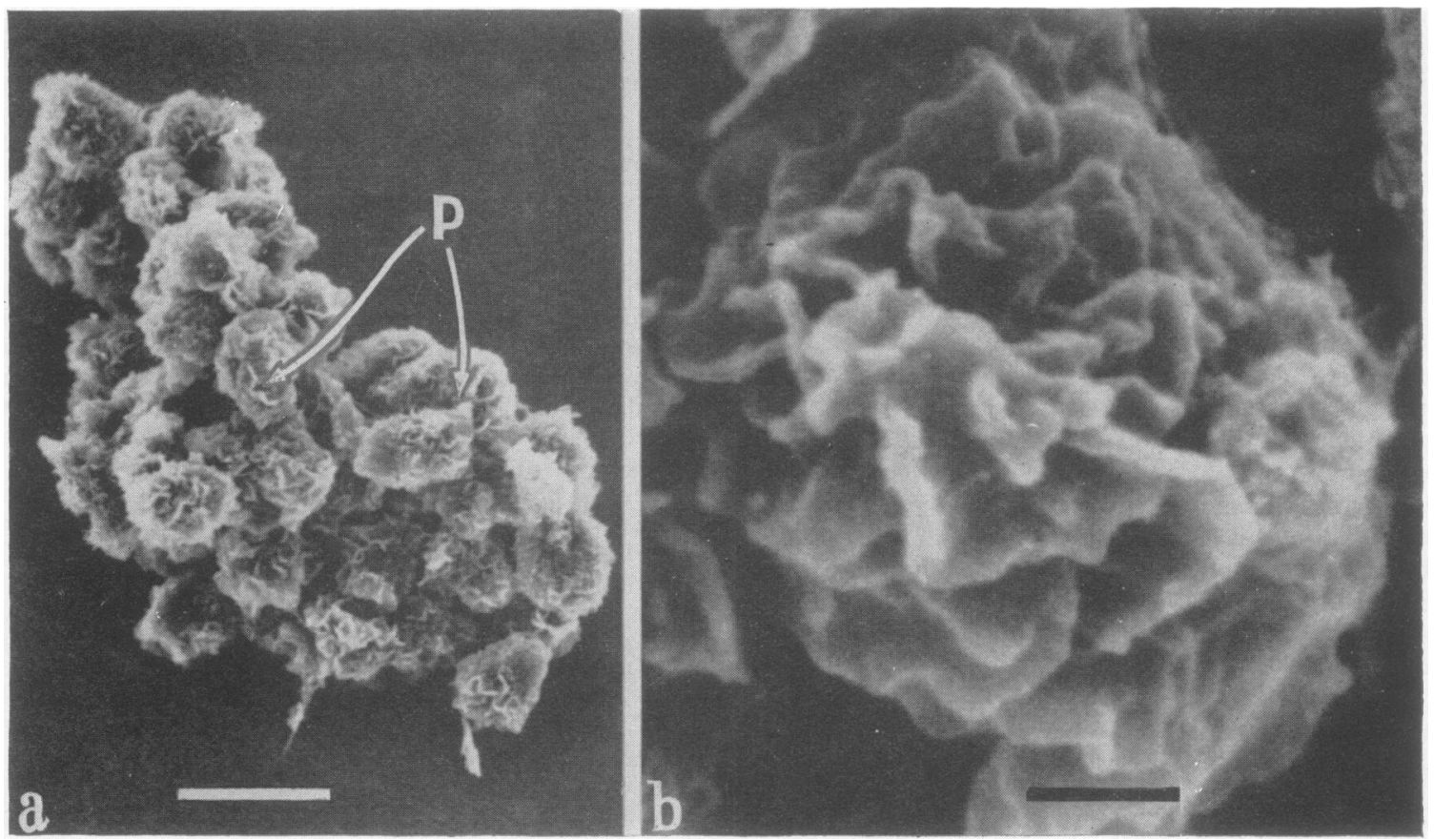

FIG. 1 Scanning electron micrographs of urethral exudate from male patient with gonorrhoea prepared for observation by the critical point drying technique (a) Cluster of phagocytes $(P)$. Marker $=10 \mu m$ (b) Higher magnification of phagocyte in urethral exudate. The ruffled membrane surface of the phagocyte membrane is evident. Marker $=1 \mu \mathrm{m}$. 

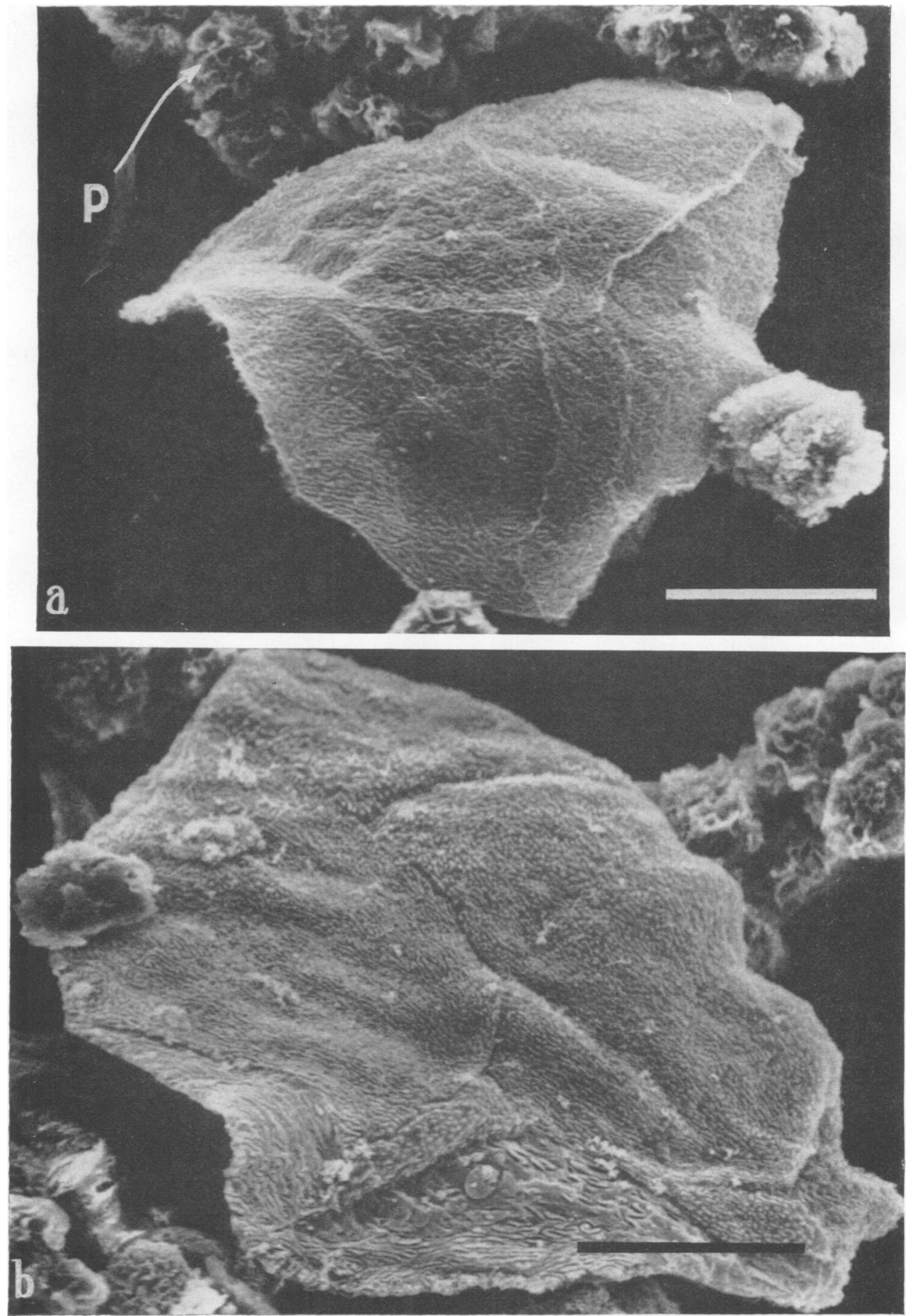

FIG. 2 Scanning electron micrographs of urethral exudate from male patient with gonorrhoea prepared for observation by the critical point drying technique (a) Convoluted surface of epithelial cell along with phagocytes $(P)$. Marker $=10 \mu \mathrm{m}$

(b) Another epithelial cell, showing rough and convoluted surface structure. Marker $=10 \mu \mathrm{m}$. 


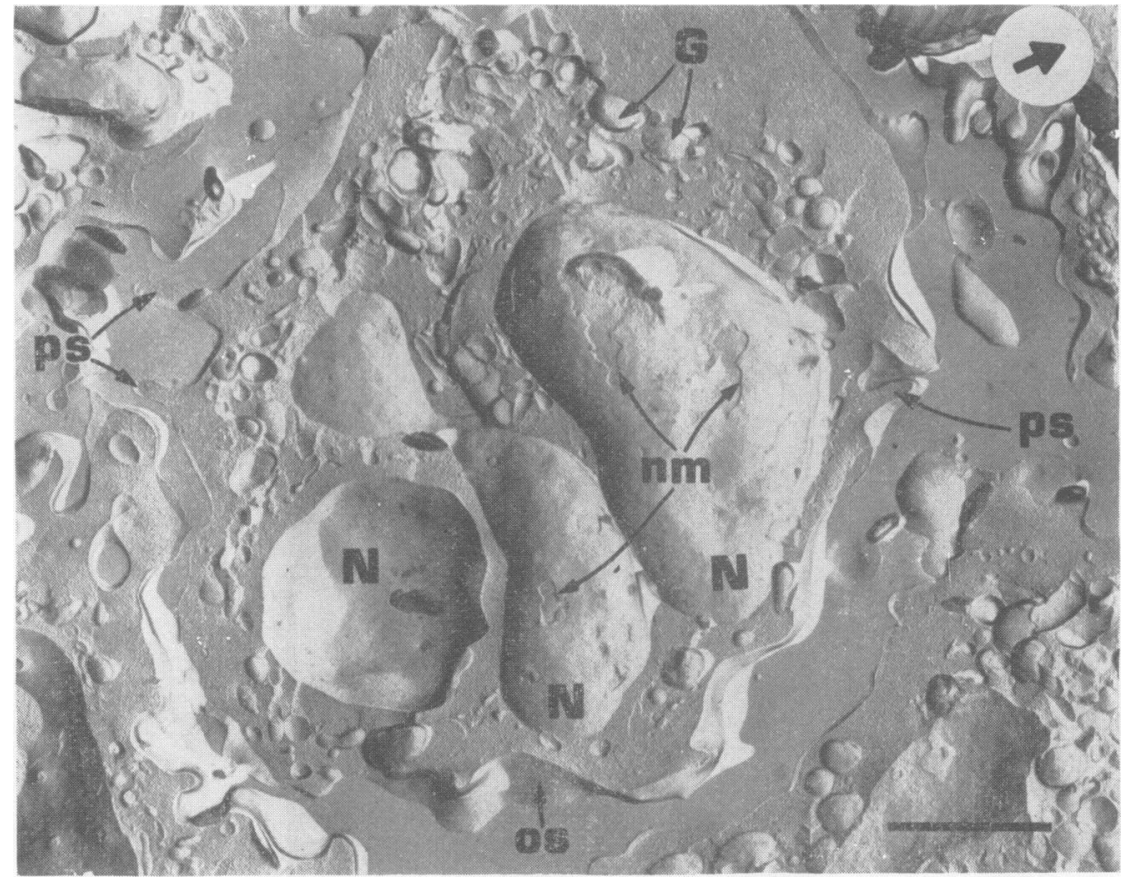

FIG. 3 Freeze-etched preparation of urethral exudate from male gonorrhoea patient, showing a polymorphonuclear cell without engulfed $\mathrm{N}$. gonorrhoeae, a multilobed nucleus $(N)$, and a nuclear membrane $(\mathrm{nm})$ fractured at several places. Smooth outer surface (os) and pseudopodia (ps) clearly visible. Cytoplasm filled with granules $(G)$ of different sizes. Marker $=1 \mu \mathrm{m}$. Arrow on upper right corner of freeze-etched preparations (Figs 3 to 8) indicates direction in which platinum was evaporated onto the specimen.

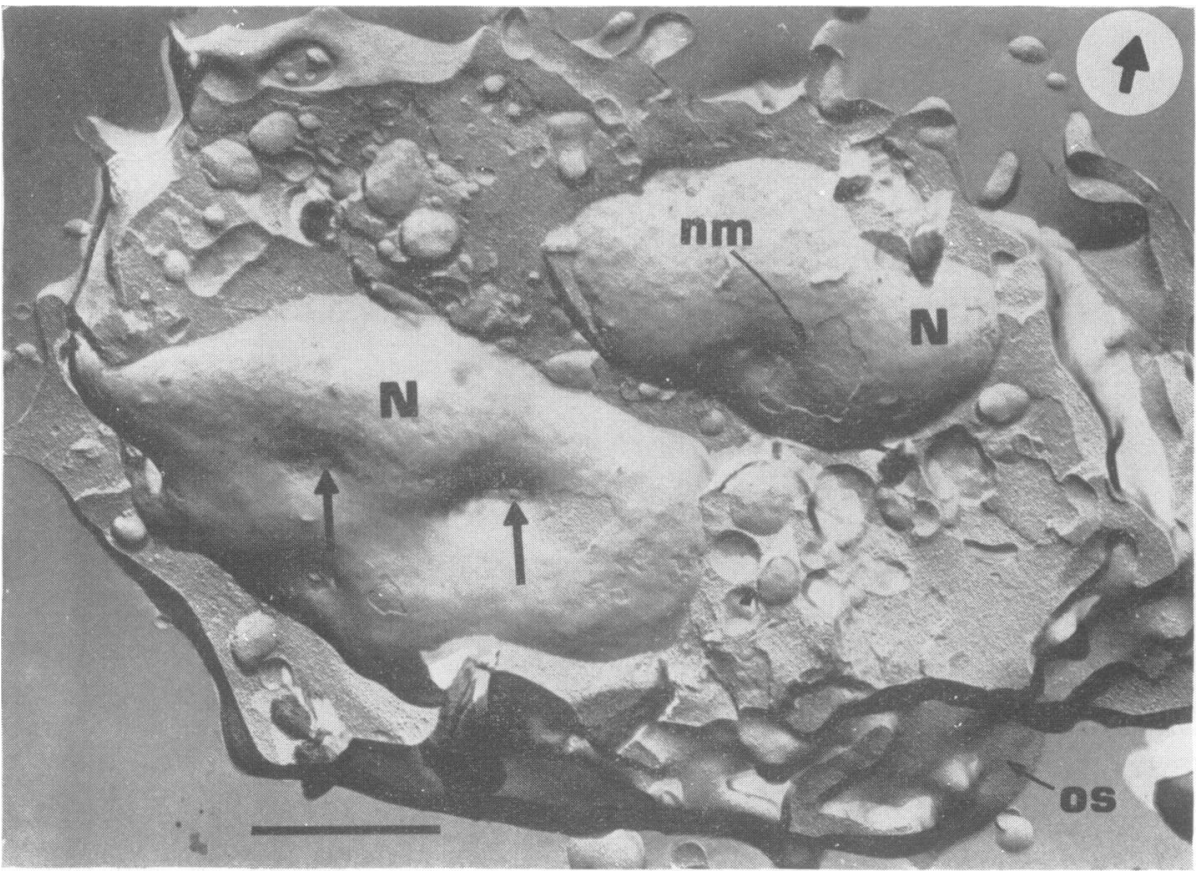

FIG. 4 Freeze-etched preparation of phagocyte in urethral exudate. Note invagination of nuclear membrane around nuclear pores (arrows). $N=$ nucleus, $n m=$ nuclear membrane, os $=$ outer surface. Marker $=1 \mu \mathrm{m}$. 


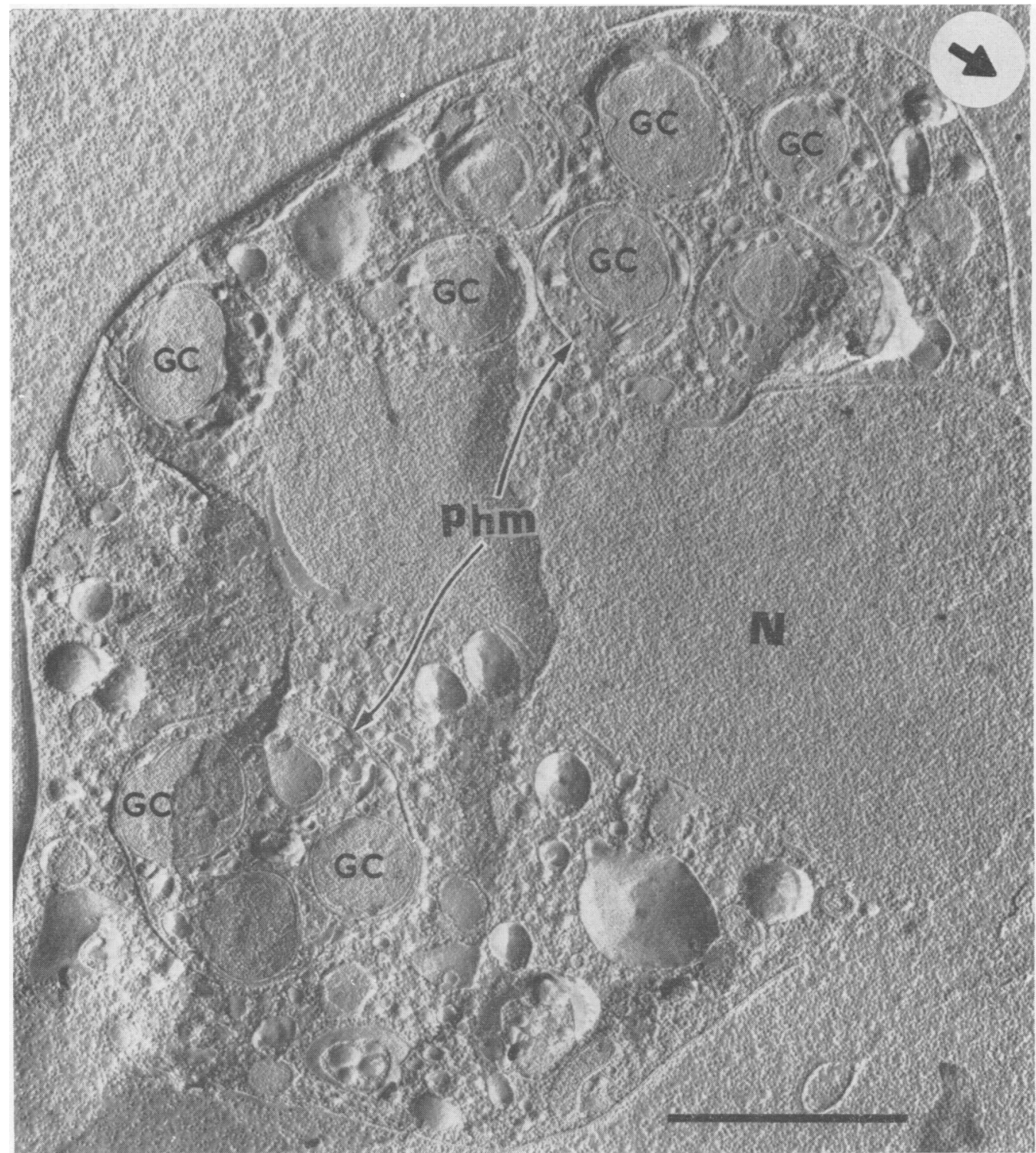

FIG. 5 Freeze-etched preparation of urethral exudate from male patient with gonorrhoea.

Phagocyte with several $\mathrm{N}$. gonorrhoeae $(G C)$ inside the phagosomes. Phagosome membranes $(\mathrm{Phm})$ clearly

In Fig. 5 a phagocyte with several gonococci (GC) inside the phagocyte is seen. As is shown in the micrograph, seven $N$. gonorrhoeae cells (GC) were phagocytosed individually, and each one appears to be surrounded by an independent phagosome membrane, while four gonococci were phagocytosed together and were surrounded by one phagosome membrane $(\mathrm{Ph} \mathrm{m})$ in another part of the cytoplasm. In this micrograph, the phagocyte still possesses some granules in the cytoplasm. visible. Seven gonococci were phagocytosed individually while four were phagocytosed together. $N=$ nucleus. Marker $=1 \mu \mathrm{m}$.

Fig. 6 shows at higher magnification six separate phagosomes, each with a bacterial cell contained within it. Several of the phagosomes have granules within the phagosome membrane. On some of the phagosomes, granules (possibly lysosomes) appear to be attached to the outside of the phagosome membrane ( $\mathrm{Ph} \mathrm{m}$ ).

Fig. 7 shows at higher magnification the phagosome from Fig. 5 containing four gonococci (GC). Some granules $(\mathrm{g})$ occur within the phagosome. 


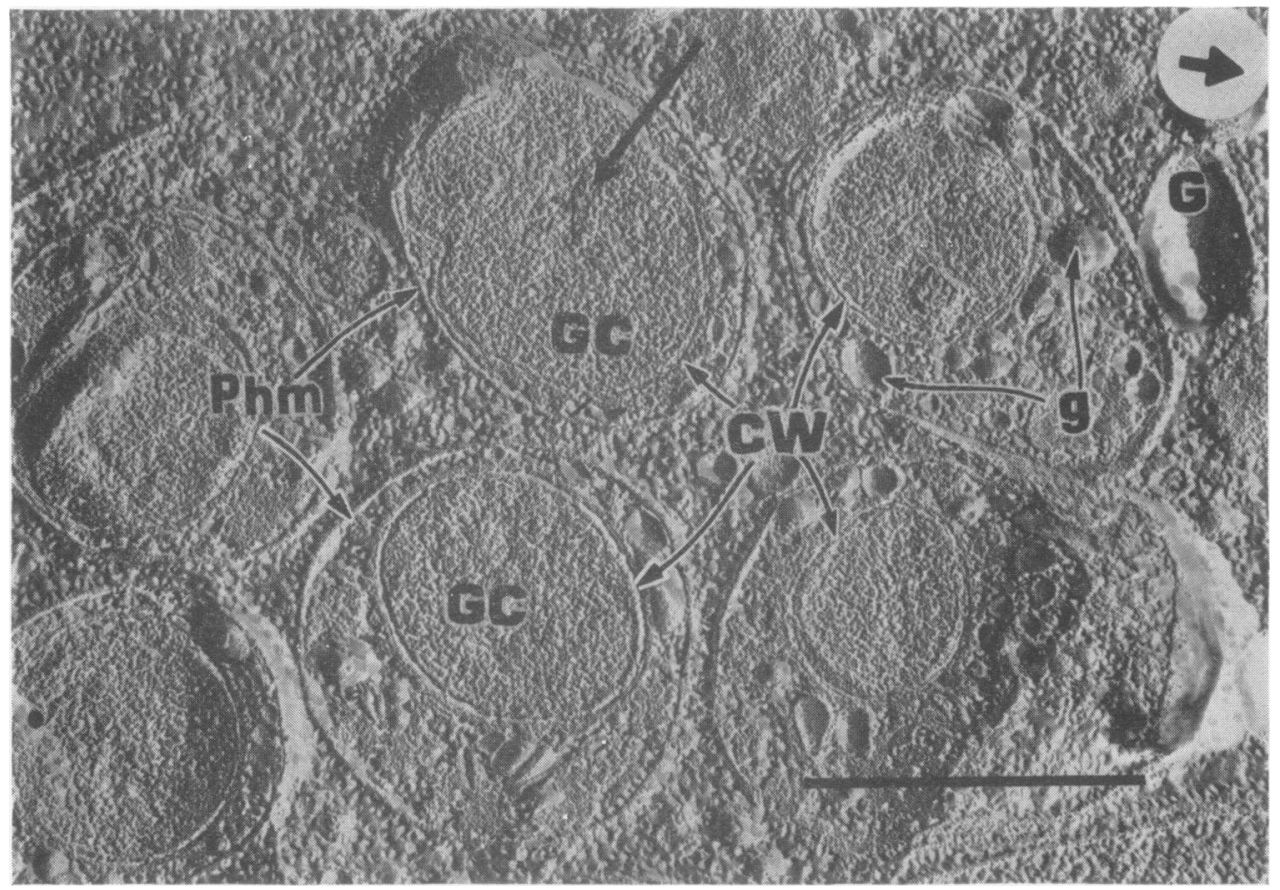

FIG. 6 Higher magnification of area in Fig. 5. $\mathrm{N}$. gonorrhoeae $(G C)$ cells, phagocytosed individually in separate phagosomes. Small granules $(g)$ also seen inside phagosome. Large granules $(G)$ attached to outside of phagosome membrane (Phm). The cell is dividing (unmarked arrow). Marker $=1 \mu \mathrm{m}$.

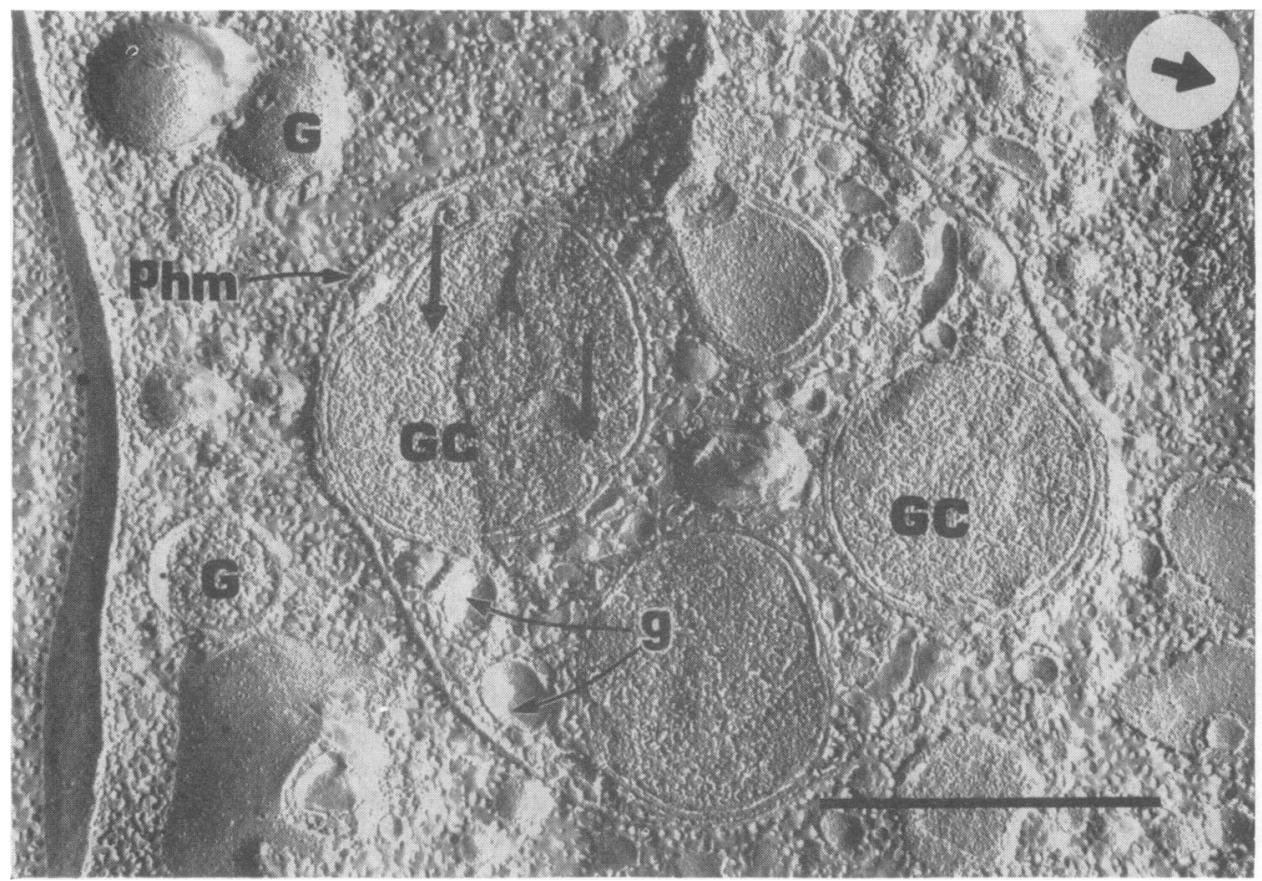

FIG. 7 Higher magnification of area in Fig 5, showing four $\mathrm{N}$. gonorrhoeae (GC) phagocytosed in one phagosome. Small granules $(g)$ visible inside phagosome and large $(G)$ granules in phagocyte cytoplasm. Note lack of septation cell wall (unmarked arrows). Phm=phagosome membrane. Marker $=1 \mu \mathrm{m}$ 
In Fig. 8 the presence of granules (g) inside a phagosome is depicted even more clearly. In this micrograph, two phagosomes are seen, one containing three such cells. Apparently, the phagosome containing only one gonococcus contains more granules within it than the phagosome with three gonococci.

\section{Discussion}

Scanning electron microscopy of urethral exudate reveals the presence of epithelial cells in addition to phagocytes (Figs. 1 and 2). The epithelial cells are possibly detached from the epithelial tissue of the urogenital tract of male patients as a result of the inflammation associated with the disease. Since gonorrhoea has been reported (Harkness, 1948) to start with a superficial infection, one might expect to see the epithelial cells in the urethral discharge from male patients. Ultra-thin sections of exudate obtained from male patients by gently scraping the epithelial tissue of the urinary tract showed the attachment of gonococci to the surface of epithelial or mucus-secreting cells (Ward and Watt, 1972). Different steps of fixation, dehydration, and criticalpoint drying in the preparation of specimens for scanning electron microscopy may have removed the gonococci from the surfaces of these cells. The rough surface of the epithelial cells (Fig. 2), when filled with mucus, provides an ideal site for attachment of gonococci. They can then establish the primary infection and are protected from removal during micturition (Ward and Watt, 1972).

The surface of the phagocytes was extensively ruffled (Figs. 1 $a, b$ ). These ruffles, which are threedimensional views of the pseudopodia, have been observed by scanning electron microscopy on peritoneal macrophages of the mouse (Klainer and Rectenwald, 1974) and the rabbit (Warfel, Elberg, and Hayes, 1973). The two dimensional views of pseudopodia provided by the light microscope and by transmission electron microscopy of ultrathin sections of phagocytes give the impression of much

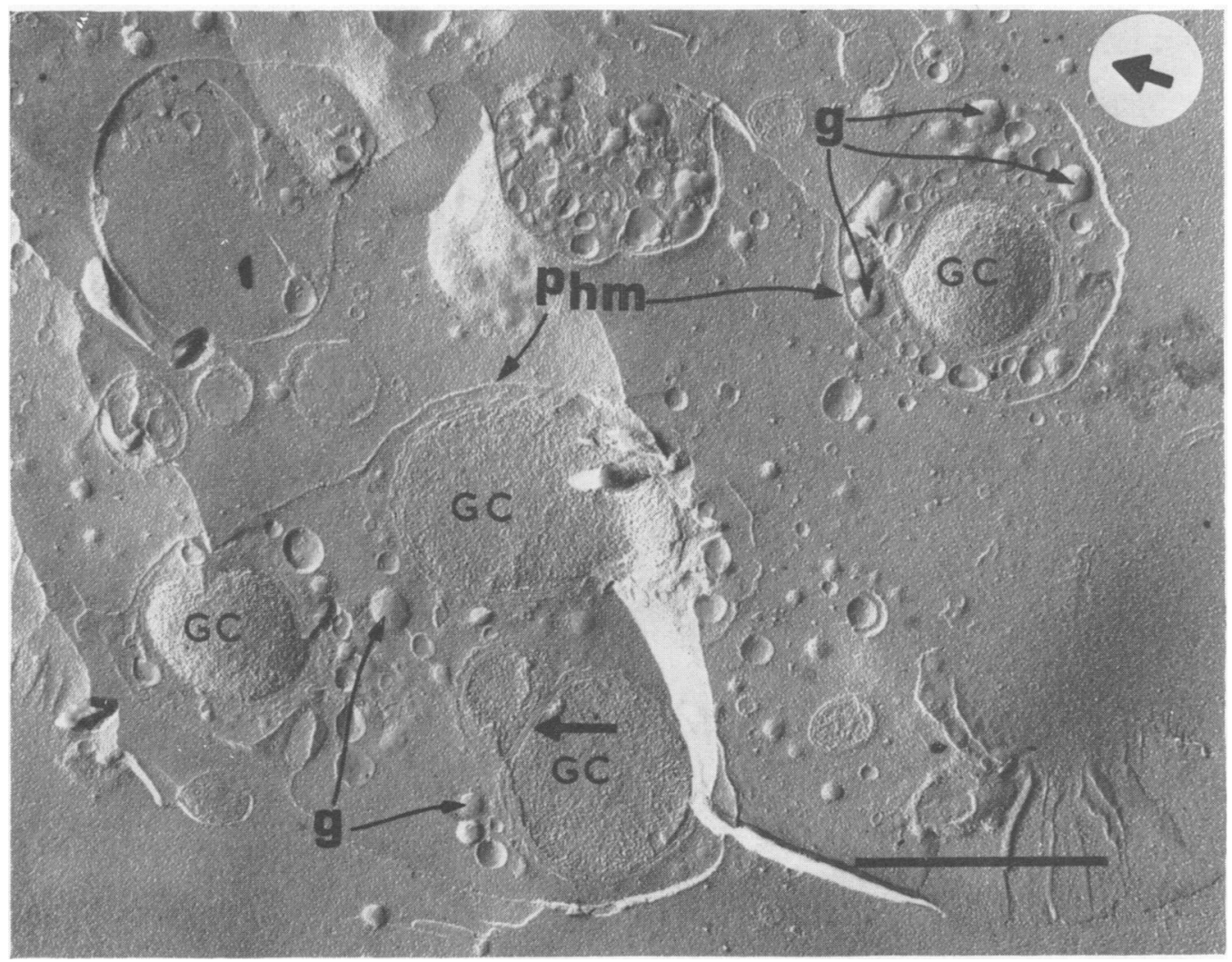

FIG. 8 Freeze-etched preparation of urethral exudate from male gonorrhoea patient. Two phagosomes are seen, one containing one $\mathrm{N}$. gonorrhoeae (GC), and the other three gonococci.

The phagosome containing one micro-organism contains more granules $(g)$ than that with several gonococci. Note presence of septation cell wall (unmarked arrow). Phm= phagosome membrane. Marker $=1 \mu \mathrm{m}$. 
less complexity in the surface of phagocytes and the number of pseudopodia. Pseudopodia were also seen on the surface of freeze-fractured, freeze-etched preparations of phagocytes (Fig. 3). Most of the phagocytes in specimens prepared by the critical point technique were found to be in clumps (Fig. 1a). The clumping of the phagocytes in urethral exudate was possibly due to the coagulation of extracellular fluids and mucus secretions during fixation and dehydration. It was our desire to handle cells as little as possible before observation; thus the urethral exudate was introduced directly from the patient into the fixative. The clumping of phagocytes could perhaps be eliminated by washing the cells before fixation as was done by Klainer and Rectenwald (1974). In freeze-etched preparations of urethral exudate, we found some phagocytes containing no gonococci in the plane of fracture (Figs. 3 and 4) and other phagocytes with as many as eleven $N$. gonorrhoeae diplococci in the plane of fracture (Fig. 5). Phagocytes with no visible bacterial cells in the fracture plane appeared to be highly granulated as seen in Fig. 3. This is in agreement with observations of phagocytes by Hirsch and Cohn (1960), who reported from their studies by phase microscopy that phagocytes degranulate after engulfing microorganisms. Ovčinnikov and Delektorskij (1971) reported granules in phagocytes without engulfed gonococci.

Figs 3 and 4 show interesting anatomical characteristics for human polymorphonuclear leucocytes. Several pseudopodia of the phagocytes were seen at any angle or level of fracture. The cell in Fig. 3 clearly reveals a trilobed nucleus. The two layers of the nuclear membrane are evident in Figs. 3 and 4. The outer layer appears smooth (Fig. 4). When the outer layer was removed as a result of freezefracturing the specimen, the inner layer was revealed and showed a rough appearance. The presence of nuclear pores was always accompanied by indentation of the pore toward the centre of the nucleus.

The majority of phagocytes with engulfed gonococci showed individual $N$. gonorrhoeae cells in one phagosome (Fig. 5). However, phagosomes containing three or more gonococci were also seen (Figs 5 and 8). Ward and others (1972) reported that, during natural infection, polymorphonuclear leucocytes are continuously phagocytosing gonococci. They showed that phagocytes are capable of destroying gonococci in $\mathbf{3 0}$ minutes. Polymorphonuclear cells containing gonococci showed evidence of degranulation (Figs 5 to 8), while those without gonococci were highly granulated (Figs 3 and 4). This supports the suggestion of Ward and Watt (1972) that gonococci cannot block the degranulation of polymorphonuclear leucocytes.

Several $N$. gonorrhoeae cells in the phagosome appear to lack the cell wail septation between the two cells and possibly these gonococci were engulfed during the process of cell division. There is also a possibility that, during natural infection, gonococci by some unknown mechanism can survive in the phagocyte and continue to divide. When exudate was studied at the level of light microscopy, as many as 25 to 50 gonococci were observed in one small area of the phagocyte, presumably in one phagosome. The preparative techniques employed for transmission electron microscopy show only a small area of the phagocyte, since both fracturing and thin sectioning reveal only a single plane through the phagosome. This might account for the lower number of gonococci seen within the phagocyte when studied by these methods.

Thomas and others (1973) showed that cells from type 1 colonies of $N$. gonorrhoeae strain F62 can resist the phagocytic action of leucocytes more than cells from type 4 colonies. Observation of the colonial type of $N$. gonorrhoeae isolated from the patients revealed 80 to 85 per cent. of colonies were type 1. Therefore, it is possible that several gonococcal cells found in one phagosome can initially resist the phagocytic action of the leucocyte, but eventually the leucocyte overcomes the resistance and destroys the engulfed micro-organisms. Destruction of gonococci by phagocytes is accompanied by migration of cytoplasmic granules, mostly lysosomes (Hirsch and Cohn, 1960) into the phagosome (Figs 6,7 , and 8). L.ysosomes inside the phagosome were found to be smaller in size than those in the cytoplasm. Ward and others (1972) reported the rupture of lysosomes in the phagosome. Possibly the smallsized granules in the phagosome are the result of partially used or ruptured lysosomes. The presence of these small granules inside the phagosome membrane containing gonococci was reported by Ward and others (1972) and Ovčinnikov and Delektorskij (1971).

The interesting finding in the observation of freeze-etched preparations of phagosomes was that the degree of granularity in the phagosomes with only one gonococcus (Fig. 8) was much greater than in those containing several $N$. gonorrhoeae. It is possible that these granules which contain different enzymes, such as Rnase, Dnase, alkaline phosphatase, lysozyme, etc. (Hirsch and Cohn, 1960), have been depleted during destruction of the gonococcal cells. We recognize that we observed only a small portion of the phagosome, and the number of bacterial cells and granules in a given phagosome cannot be established from one fracture. In freeze-etching there is no equivalent to the serial-sectioning technique used with plastic-embedded specimens.

This is the first demonstration of $N$. gonorrhoeae within polymorphonuclear leucocytes in urethral exudates by the freeze-etch technique. The appearance and surface morphology of phagocytes and 
epithelial cells in urethral exudates of male gonorrhoea patients are also shown here for the first time by scanning electron microscopy. The phagocytes observed had been exuded through a natural body opening as a result of the gonorrhoeal infection. This allowed us to observe phagocytes which were naturally produced as a result of disease. In addition, the specimens were minimally manipulated after collection from the patients, being fixed with the mildest of fixatives, 2 per cent. glutaraldehyde. In the case of the freeze-etch preparations, even dehydrating agents were avoided, thus eliminating another insult to cellular structures. The use of these two methods of study with minimal manipulation of specimens may lead to a better understanding of phagocytosis in general and more specifically to a better understanding of the pathogenesis of gonorrhoea. Unfortunately we have been unable, as yet, to observe the gonococcal cell in the process of being phagocytosed by either method. This would probably require the observation of many more specimens.

\section{Summary}

Urethral exudates from male patients with gonorrhoea were studied by use of the critical point drying technique for scanning electron microscopy. The surfaces of phagocytes were extensively ruffled. This was interpreted to be the three-dimensional appearance of pseudopodia. Epithelial cells present in the urethral exudate showed a highly convoluted surface structure.

Specimens of urethral exudate prepared by the freezeetch technique showed that most $N$. gonorrhoeae were engulfed individually in phagocytes. Some phagosomes contained two or more gonococcal cells. Phagocytes containing gonococci were degranulated, but small granules were present in the phagosomes. Nuclear pores on the surface of the nuclear membrane were always associated with an indentation of the nuclear membrane. The outer layer of the nuclear membrane was smooth compared to the inner layer.

\section{References}

Anderson, T. F. (1951) Trans. N.Y. Acad. Sci., 13, 130

HARKNess, A. H. (1948) Brit. F. vener. Dis., 24, 137

Hirsch, J. G., and CoHn, Z. A. (1960) F. exp. Med., 112, 1005
Kellogg, D. S., Cohen, I. R., Norins, L. C., SCHROETER, A. L., and Reising, G. (1968) f. Bact., 96, 596

-, Peacock, W. L., Deacon, W. E., Brown, L., and PIRKLE, C. I. (1963) Ibid., 85, 1274

KLAINER, A. S., and RECTENWALD, M. (1974) 'Scanning Electron Microscopy', ed. O. Johari and I. Corvin, p. 822. Illinois Institute of Technology Research Institute, Chicago

MARTiN, J. E., Jr., and Lester, A. (1971) HSMHA Hlth Rep., 86, 30

OvčinNikov, N. M., and DelektorskiJ, V. V. (1971) Brit. f. vener. Dis., 47, 419

SPINK, W. W., and KeEFER, C. S. (1937) f. clin. Invest., 16, 169

Thomas, D. W., Hill, J. C., and TyeryaR, F. J., Jr (1973) Infect. and Immun., 8, 98

WARD, M. E., GlynN, A. A., and WATt, P. J. (1972) Brit. F. exp. Path., 53, 289

— and WATt, P. J. (1972) F. infect. Dis., 126, 601

Warfel, A. H., Elberg, S. S., and HaYes, T. L. (1973) Infect. and Immun., 8, 665

Etude par microscope électronique à balayage et cryo-décapage ${ }^{\star}$ des sécrétions urétrales gonococciques

\section{SOMMAIRE}

Des sécrétions urétrales d'hommes atteints de gonococcie furent étudiées à l'aide de la technique du point critique pour le balayage en microscopie électronique. Les surfaces des phagocytes étaient extrêmement ridées. Ceci fut interprété comme l'apparence tri-dimensionnelle de pseudopodes. Les cellules épithéliales présentes dans la sécrétion urétrale montraient une structure de surface fortement convolutée. Les spécimens de la sécrétion urétrale étudiées par cryo-décapage montraient que la plupart des $N$. gonorrhoeae étaient inclus individuellement dans les phagocytes. Quelques phagosomes contenaient deux ou un plus grand nombre de cellules gonococciques. Les phagocytes contenant des gonocoques avaient perdu leurs granulations mais de petits granules étaient présents dans les phagosomes. Les pores nucléaires à la surface de la membrane nucléaire correspondaient toujours avec une empreinte en creux de la membrane nucléaire. La couche externe de la membrane nucléaire était lisse par comparaison avec la couche interne.

^NDT - attaque par congélation 